\title{
KONSEP UANG DALAM PERSPEKTIF EKONOMI ISLAM
}

\author{
Muchammad Ichsan \\ Magister Ilmu Hukum, Universitas Muhammadiyah Yogyakarta \\ E-Mail: drichsan65@yahoo.com
}

\begin{abstract}
Abstrak: Manusia telah menggunakan uang sebagai alat untuk bertransaksi sejak lama sekali. Uang yang digunakan sebagai mata uang resmi sejak zaman Nabi Muhammad saw. dan diteruskan oleh para Khalifah setelahnya selama berabad-abad lamanya adalah uang dinar emas dan dirham perak. Makalah ini bertujuan untuk membentangkan konsep uang menurut perekonomian Islam. Untuk tujuan tersebut, metode kajian hukum normative dipakai dalam penulisannya. Data diambil dari sumber data primer dan sekunder. Di antara temuan kajian ini ialah bahwa dalam perspektif ekonomi Islam, uang adalah segala sesuatu yang diterima secara umum dan diterbitkan oleh lembaga keuangan yang berwenang sebagai media pertukaran dan pengukur serta penyimpan nilai. Selain itu, penggunaan uang dinar emas dan dirham perak bukan suatu kewajiban agama, tapi sejarah membuktikan bahwa dua mata uang tersebut sangat stabil dan tidak terkena inflasi sebagaimana uang kertas. Menurut perspektif ekonomi Islam, uang mempunyai tiga fungsi yaitu sebagai alat tukar, sebagai satuan hitung atau pengukur nilai, dan sebagai penyimpan nilai apabila uang terbuat dari emas dan perak. Dalam bidang keuangan, Islam mempunyai banyak ketentuan, antara lain seperti penggunaan uang sebagai alat pengukur nisab dan kadar zakat, mahar, kaffarah, nisab potong tangan bagi pencuri, diyat, dan jizyah.
\end{abstract}

Kata Kunci: Uang; Dinar; Dirham; Emas; Ekonomi Islam.

\section{PENDAHULUAN}

Kebutuhan manusia terhadap harta pada umumnya dan uang pada khususnya tidak bisa dinafikan. Sejak zaman dahulu, manusia membutuhkan uang untuk mempermudah mereka dalam melakukan transaksi dan pertukaran. Dengan menggunakan uang berarti mereka meninggalkan sistem barter yang rumit dan menyusahkan.

Uang adalah salah satu inovasi besar manusia sepanjang peradaban. Uang mempunyai posisi yang sangat strategis dalam sistem perekonomian dunia, sehingga tidak mudah untuk menggantinya dengan media lainnya. Sejarah membuktikan, uang mempunyai peran penting dalam kehidupan manusia, khususnya dalam bidang perekonomian. Uang memudahkan dan mempersingkat waktu transaksi pertukaran barang dan jasa. Uang membuat perdagangan berjalan secara efektif dan efisien. Uang merupakan alternatif transaksi yang lebih mudah daripada sistem barter yang kompleks, rumit, tidak efisien, dan tidak sesuai digunakan dalam sistem perekonomian modern (Takiddin, 2014).

Perekonomian Islam, sebagai bagian dari Islam memiliki konsep yang jelas dalam masalah harta pada umumnya dan uang pada khususnya. Perekonomian Islam mempunyai pandangan tersendiri terhadap uang. Ia menerangkan jenis dan fungsi uang dan mengatur apa yang boleh dilakukan dan apa yang tidak boleh dalam masalah uang sebagai pedoman untuk umat.

Kajian ini bertujuan untuk mendiskripsikan konsep uang menurut perspektif perekonomian Islam. Di antara hal yang dibahas adalah definisi uang, 
sejarah uang, jenis uang, dan fungsi uang serta ketentuan-ketentuan Islam mengenai uang.

Kajian seputar konsep uang dalam perspektif ekonomi Islam sangat urgen dilakukan untuk memaparkan keistimewaan konsep uang yang Islami apabila dibandingkan dengan konsep uang menurut sistem kapitalis. Lebih dari itu, diharapkan konsep uang yang Islami itu dapat diterapkan dalam perekonomian umat, sehingga kesejahteraan dan kemakmuran ekonomi di dunia diperolehi, dan nanti apabila sudah berada di alam akhirat, al-falah yakni kebahagiaan hakiki di dalam sorga juga akan dicapai.

\section{PEMBAHASAN}

Kajian tentang konsep uang dalam perspektif ekonomi Islam mencakup hal-hal yang luas. Dalam makalah ini, pembahasan dibatasi pada hal-hal berikut; (a) Definisi dan sejarah uang, (b) Jenis uang, dan (c) Fungsi uang dan Ketentuan Islam dalam masalah uang.

\section{Definisi dan sejarah uang.}

Ilmu ekonomi tradisional mendefinisikan uang sebagai setiap alat tukar yang dapat diterima secara umum. Benda apapun dapat menjadi alat tukar selama diterima oleh semua orang untuk proses pertukaran barang dan jasa. Sedikit berbeda dengan ilmu ekonomi tradisional, ilmu ekonomi modern mendefinisikan uang sebagai sesuatu yang tersedia dan secara umum diterima sebagai alat pembayaran untuk pembelian barang, jasa dan kekayaan berharga lainnya serta untuk pembayaran hutang. (Takiddin, 2014).

Dari dua definisi di atas didapati bahwa uang pada zaman dahulu berfungsi sebagai alat tukar, sementara pada zaman modern, uang berfungsi sebagai alat bayar, baik untuk membayar barang, jasa maupun hutang. Dua definisi di atas juga mengisyaratkan bahwa uang itu mengalami perkembangan dan mempunyai sejarah panjang.

Sejarah uang secara pasti tidak diketahui kapan bermula, namun yang pasti, pada mulanya masyarakat zaman purbadahulubelummengenal pertukaran, karena setiap orang pada waktu itu berusaha untuk memenuhi kebutuhan hidupnya dengan usaha sendiri. Mereka mencari tumbuh-tumbuhan dan tanaman yang ada di persekitaran untuk dimakan apabila lapar, dan mereka berburu binatang apabila ingin makan daging. Mereka membuat sendiri pakaian yang melindungi diri dari cuaca panas dan dingin, dan mereka membangun sendiri rumah dari bahan-bahan sederhana yang ada di sekitar mereka. Ringkasnya, mereka mengusahakan sendiri kebutuhan mereka.

Selanjutnya, sejalan dengan perkembangan zaman, manusia mendapati bahwa mereka tidak sanggup memenuhi seluruh kebutuhan mereka dengan usaha sendiri. Oleh karena itu, mereka berusaha mendapatkan orangorang yang mau saling menukarkan barang-barang sehingga muncullah sistem "barter" yaitu pertukaran barang dengan barang. Tapi ternyata ternukti bahwa sistem barter juga menimbulkan banyak kesulitan-kesulitan, antara lain kesulitan untuk menemukan orang yang mempunyai barang yang diinginkan, dan dalam waktu yang sama, mau menukarkan barang yang dimilikinya itu, serta kesulitan untuk mempertukarkan barang yang mempunyai nilai tukar yang sama atau hampir sama.

Untuk mengatasi permasalahan tersebut, timbul pikiran untuk menggunakan barang-barang tertentu sebagai alat tukar. Barang atau benda yang ditetapkan sebagai alat pertukaran itu mempunyai ciri-ciri antara lain; harus berupa barang-barang yang diterima oleh umum dan bernilai tinggi, atau memiliki 
nilai magis dan mistik, atau sangat dibutuhkan sehari-hari.

Setelah alat tukar ada, ternyata orang masih mengalami kesulitan-kesulitan, yaitu antara lain barang-barang yang menjadi alat tukar itu tidak bisa dipecah menjadi pecahan-pecahan sehingga timbul masalah untuk menentukan harga dengannya serta menyimpan dan mengangkut uang yang berupa barangbarang tersebut. Belum lagi kesulitan lain seperti kurangnya daya tahan barangbarang tersebut sehingga mudah rusak atau musnah.

Maka pada tahap selanjutnya muncullah uang logam. Logam dipilih karena mempunyai ciri-ciri antara lain memiliki nilai tinggi, digemari banyak orang, mudah dipecah tanpa mengurangi nilai, berdaya tahan lama, tidak cepat rusak, dan mudah dipindahkan karena lebih ringan. Logam yang memiliki ciriciri tersebut adalah emas dan perak, sehingga keduanya layak untuk dijadikan alat tukar. Selain itu, uang emas dan perak mempunyai kelebihan lain yaitu uang emas dan perak disebut dengan uang penuh (full body money). Artinya, nilai intrinsik (nilai bahan) uang sama dengan nilai nominalnya (nilai yang tercantum pada mata uang tersebut).

Setelah uang logam digunakan dalam jangka yang lama, timbul kesulitan lain yaitu bahwa uang logam emas dan perak itu, karena jumlahnya yang terbatas, semakin kewalahan memenuhi transaksi yang semakin berkembang. Oleh karena itu, untuk mengatasinya dibuatlah uang kertas. Uang kertas pada asalnya merupakan bukti kepemilikan emas dan perak yang berperan sebagai alat atau perantara transaksi. Dengan demikian, uang kertas yang berlaku dan beredar pada waktu itu dijamin $100 \%$ dengan emas dan perak yang disimpan di pandai emas dan perak.

Pencetakan uang kertas tidak boleh dilakukan oleh Negara manapun secara sembarangan tanpa adanya jaminan stok emas yang mencukupi. Sistem penjaminan uang dengan emas ini disebut "sistem standar emas" yang muncul pada tahun 1870. Hal itu dimulai dengan penetapan pemerintah Inggris terhadap nilai poudsterling dengan emas. Sistem standar emas ini dipakai banyak Negara sejalan dengan perkembangan industri dan perdagangan dunia. Namun penggunaan sistem ini berakhir pada masa Perang Dunia I. Akibatnya, sistem keuangan di banyak Negara menjadi kacau dan rusak.

Oleh karena itu, sebuah konferensi yang dihadiri oleh 730 delegasi dari 44 negara diselenggarakan pada tanggal 1-22 Juli 1944 di Bretton Woods, di sebuah kota kecil di negara bagian New Hampshire, Amerika Serikat. Hasil dari konferensi tersebut disebut dengan "sistem Bretton Woods." Sistem Bretton Woods ini menetapkan dolar Amerika menggantikan emas sebagai standar utama pertukaran mata uang dunia, dan hanya dolar Amerika satu-satunya mata uang yang didukung oleh emas. Selain itu, berdasarkan sistem Bretton Woods ini, setiap mata uang kertas dari negara anggota dipatok terhadap dolar Amerika Serikat dengan jaminan emas, yaitu setiap 35 dolar AS dijamin dengan satu ounce emas.

Namun pada awal tahun 1970-an, Pemerintah Amerika Serikat mengalami kesulitan ekonomi akibat perang Vietnam, ditambah lagi dengan menipisnya cadangan emas, sehingga cadangan emas yang dimilikinya tidak mampu lagi menjamin uang kertas. Pemerintah AS membuat keputusan untuk tidak lagi menjamin dolar AS dengan emas akibat banyaknya aliran penukaran dolar AS dengan emas. Sehingga pada akhirnya, Amerika Serikat mengumumkan kepada dunia pada tanggal 15 Agustus 1971 bahwa tidak akan ada lagi pertukaran emas untuk dolar. Dengan ini, sistem 
Bretton Woods berakhir dan tidak dipakai lagi.

Sejak saat itulah emas tidak menjadi jaminan mata uang kertas. Uang kertas ditentukan nilainya oleh kepercayaan yang didukung ketersediaan cadangan devisa berupa emas dan valuta asing yang dimiliki oleh bank sentral masingmasing negara. Negara-negara dunia pada akhirnya menerima penggunaan nilai tukar mengambang (floating rate) melalui Jamaica Agreement tahun 1976. Ini berarti bahwa penggunaan standar emas akan dihapus secara permanen (Ari, 2013) dan (Kurniawan, 2012).

Dalam sejarah Islam, uang sudah ada pada zaman Nabi Muhammad SAW. Pada waktu itu uang yang digunakan ada dua; yaitu dinar yang terbuat dari emas dan dirham yang terbuat dari perak. Dinar emas dan dirham perak sebenarnya sudah ada jauh sebelum zaman Nabi Muhammad SAW., dan ketika memimpin umat, beliau memberlakukan mata uang resmi dengan mengadopsi dinar emas dan dirham perak. Hal ini kemudian diikuti oleh para khalifah yang memimpin setelah beliau wafat selama beberapa abad.

Sayangnya, hari ini uang dinar dan dirham hanya tinggal nama. Tidak ada sebuah Negara pun yang didiami umat Islam yang menggunakannya sebagai mata uang resmi. Masing-masing Negara kini mempunyai mata uang yang berbasis pada mata uang fiat atau kertas. Negaranegara umat Islam yang hingga kini masih menggunakan nama "dinar" atau "dirham" sebagai mata uang resmi, mereka tidak mendasarkannya lagi kepada emas dan perak, tetapi kepada kertas.

Karim (2007) menegaskan bahwa pada masa Rasulullah saw. uang yang digunakan oleh umat Islam adalah dinar emas Romawi dan dirham perak Persia tanpa mengubahnya. Sementara khalifah Bani Umayah yang bernama
Abdul Malik bin Marwan adalah khalifah pertama yang mencetak dinar emas dan dirham perak dengan lambang Islami pada tahun $74 \mathrm{H}$ untuk diberlakukan di negara Islam. Pemerintah-pemerintah Islam sesudahnya melanjutkan kebijakan pencetakan uang Islami ini. Tapi uang kertas mulai beredar dan berlaku di banyak wilayah Islam pada akhir Daulah Utsmaniyah sekitar tahun 1922.

Ada beberapa istilah dalam literatur hukum Islam untuk menyebut uang, yaitu antara lain: nuqud, tsaman, fulus, sikkah dan 'umlah (Karim, 2007). Para ulama menggunakan semua istilah ini untuk menunjuk uang meskipun ternyata masing-masing istilah mempunyai arti berbeda.

Nuqud menurut sebagian ulama adalah segala sesuatu yang digunakan untuk melakukan transaksi oleh masyarakat, baik berupa dinar emas, dirham perak maupun fulus tembaga. Sementara sebagian ulama lainnya berpendapat bahwa nuqud berupa apapun yang diterima secara umum untuk menjadi media pertukaran dan pengukur nilai. Selain itu, Qal'ah Ji mendefinisikan nuqud sebagai sesuatu yang dijadikan harga oleh masyarakat, baik terdiri dari logam atau kertas yang dicetak maupun dari bahan lainnya dan diterbitkan oleh lembaga keuangan pemegang otoritas.

Tsaman mempunyai beberapa arti yaitu antara lain berarti nilai sesuatu dan harga pembayaran barang yang dijual. Arti lain tsaman ialah uang emas dan perak.

Fulus adalah logam dari tembaga yang diterima dan digunakan oleh masyarakat sebagai uang dan alat pembayaran barang-barang yang remeh.

Sikkah dipakai untuk dua arti berikut: (1) stempel besi untuk mencap mata uang, dan (2) mata uang dinar dan dirham yang telah dicetak dan distempel.

'Umlah mempunyai dua pengertian berikut: (1) satuan mata uang yang 
berlaku di suatu negara, misalnya rupiah adalah 'umlah yang berlaku di Indonesia, dan dinar adalah 'umlah di Yordania, dan

(2) mata uang dalam arti umum, sama dengan nuqud.

Istilah yang sering digunakan dan paling tepat untuk menunjukkan uang seperti yang dipahami masyarakat luas sekarang adalah nuqud dan tsaman.

Sementara al-Qur'an menggunakan beberapa istilah untuk menunjukkan uang dan fungsinya, baik sebagai alat pengukur nilai maupun penyimpan nilai. Istilah yang digunakan antara lain dinar, dirham, emas dan perak. Kata "dinar" hanya disebut satu kali dalam QS. Ali Imran, (3): 75, kata "dirham" juga hanya disebutkan satu kali saja yaitu dalam QS. Yusuf, (12): 20, kata "emas" disebut sebanyak delapan kali, yaitu antara lain di dalam QS. AtTaubah, (9): 34, dan kata "perak" disebut enam kali, yaitu antara lain di dalam QS. al-Kahfi, (18): 19. (Muthoifin, 2013)

\section{Jenis uang.}

Sepanjang sejarah, masyarakat dunia pada umumnya telah menggunakan berbagai jenis uang. Ada uang berupa binatang ternak dan ada pula uang berupa garam. Ada uang yang terbuat dari logam emas, perak dan tembaga, dan ada pula yang terbuat dari kertas.

Dalam Islam, Nabi Muhammad SAW. dan para khalifah setelah beliau memilih dan mengadopsi logam dari emas dan perak sebagai mata uang resmi. Mata uang dari emas disebut dinar dan yang terbuat dari perak disebut dirham. 1 dinar emas adalah 4.25 gram emas murni, dan 1 dirham adalah 2.975 gram perak murni. Pernah Umar bin Khattab ketika menjadi khalifah berkeinginan untuk membuat uang dari kulit onta. Namun masyarakat Islam pada waktu itu menolaknya. Kata Umar: "Ketika aku akan membuat uang dari kulit unta, ada orang yang protes dengan mengatakan: "kalau begitu unta akan punah", sehingga aku membatalkan keinginan itu." (Iqbal, 2012).

Semenjak itu hingga beberapa abad kemudian, tidak ada upaya menggantikan dinar emas dan dirham perak. Dinar emas dan dirham perak dipilih sebagai mata uang resmi karena mempunyai ciri-ciri antara lain memiliki nilai tinggi, disukai banyak orang, berlaku di manamana, tahan lama, tidak mudah rusak, mudah dipecah tanpa mengurangi nilai, dan mudah dipindahkan. Kelebihan lain dari uang emas dan perak ialah uang tersebut disebut uang penuh (full body money) yang berarti bahwa nilai intrinsik atau nilai bahan pembuatan uang tidak berbeda dengan nilai nominal uang itu, yaitu nilai yang tercantum pada mata uang tersebut.

Pertanyaannya, apakahmenggunakan dinar emas dan dirham perak sebagai mata uang resmi itu adalah kewajiban yang harus dilakukan menurut perspektif ekonomi Islam? Perlu ditegaskan bahwa penggunaan dinar emas dan dirham perak bukan suatu kewajiban. Al-Iraqi (2013) menyatakan bahwa jumhur atau mayoritas ulama berpendapat bahwa menggunakan dinar dan dirham sebagai mata uang umat Islam itu disyariatkan (dilegalkan) dan hukumnya mubah atau boleh. Dengan demikian, umat Islam boleh menggunakan uang dari jenis lain selain emas dan perak. Bahkan pada masa pemerintahan Islam dahulu, umat Islam pernah menggunakan fulus atau uang dari tembaga sebagai alat pembayaran barang-barang yang sepele atau murah dan sebagai tambahan pelengkap terhadap mata uang dinar emas dan dirham perak.

Namun perlu segera ditekankan di sini bahwa penggunaan dinar emas dan dirham, meskipun bukan suatu kewajiban, tapi sejarah membuktikan bahwa penggunaan keduanya itu tidak menimbulkan masalah, bahkan sebaliknya, kestabilan ekonomi dapat terjaga dan kemakmuran hidup dapat 
tercapai dengannya. Hal ini karena nilai keduanya sangat stabil sepanjang sejarah. Selain itu, nilai suatu mata uang itu selama tidak bersandar kepada emas dan perak akan selalu turun tidak menentu. Inilah yang disebut inflasi. Inflasi ialah keadaan di mana nilai mata uang merosot dibandingkan dengan harga barang. Hal ini karena banyaknya uang yang beredar di tengah-tengah masyarakat. Akibatnya, masyarakat merasakan harga barang menjadi semakin mahal dari sebelumnya.

Dibanding dengan uang kertas, nilai dinar emas dan dirham stabil selama berabad-abad dan tidak mengalami inflasi yang signifikan. Sebaliknya, inflasi telah mengiringi mata uang kertas sejak kelahirannya, dan inflasi akan terus mengiringinya sampai kapanpun. Tambahan pula, uang fiat atau kertas yang kini digunakan sebagai mata uang resmi oleh seluruh umat manusia di semua negara itu problematis karena semuanya bersandarkan kepada dolar Amerika. Kondisi ini membuat perekonomian Amerika akan berpengaruh pada kondisi perekonomian negara-negara lain dan membuat mereka selalu bergantung kepada dolar Amerika. Dengan bersandar kepada mata uang fiat atau kertas, hegemoni dan dominasi dolar Amerika dan mata uang negara-negara maju tidak akan dapat ditandingi dan apalagi diatasi oleh negara-negara berpenduduk Muslim yang notabene merupakan negara berkembang (Ichsan, 2017).

Penggunaan dinar emas dan dirham perak sebagai mata resmi Negara-negara yang didiami umat Islam pada masa kini juga mempunyai banyak manfaat, antara lain menurut Ichsan (2017):

(1) Menyatukan umat Islam. Dengan dinar emas dan dirham perak, umat Islam yang kini terpecah-pecah dalam beberapa negara kecil dan belum bisa disatukan dari segi politik, akan dapat disatukan di dalam sistem moneter, tanpa mencampuri urusan politik masing-masing negara. Umat Islam tidak boleh ketinggalan dengan Negara-negara Eropa yang telah menyatukan mata uang mereka dalam Euro.

$$
\text { Mensejahterakan }
$$

umat. Kesejahteraan umat Islam di banyak negara akan semakin meningkat dengan penggunaan dinar emas dan dirham perak sebagai alat tukar dan penyimpan harta. Bahkan seluruh umat manusia akan merasakan kesejahteraan apabila mereka semua mau menggunakan dinar emas dan dirham perak. Hal ini tidak mengherankan, karena menurut Sanhu (2012), dinar emas dan dirham perak bersifat universal dan terbukti sepanjang sejarah tidak terkena inflasi maupun deflasi.

(3) Membebaskan umat dari sistem bunga uang yang merupakan sistem perbankan. Sistem bunga uang yang dipakai oleh perbankan yang disepakati oleh banyak ulama sebagai riba yang diharamkan oleh Allah dan RasulNya akan ditinggalkan apabila dinar emas dan dirham perak diberlakukan sebagai mata uang resmi umat Islam. Hal ini karena emas dan perak bebas dari pengaruh sistem perbankan yang selalu dilanda krisis. Emas dan perak juga tidak akan pernah bisa terikat oleh sistem bunga sebagaimana uang kertas.

(4) Membebaskan dari ketergatungan kepada dolar Amerika. Ketergantungan umat Islam kepada dolar Amerika dengan segala dampaknya akan hilang dengan pemberlakuan dinar emas dan dirham perak. Sebaliknya, selama umat Islam tidak bisa melepaskan diri dari ketergantungan kepada dolar Amerika maka maka dolar Amerika akan terus-menerus mempengaruhi dan mendominasi perekonomian mereka. Lebih dari itu, menurut Ari (2013) krisis moneter yang terjadi di Amerika pasti akan berdampak kepada semua negara yang mengakui dolar Amerika. 
(5) Lebih adil untuk semua, terutama untuk negara-negara berkembang. Penggunaan kembali dinar emas dan dirham perak lebih adil bagi umat manusia terutama umat Islam yang nota bene masih tinggal di negara-negara berkembang. Hal ini karena dinar emas dan dirham perak adalah uang sebenarnya yang bersifat universal. Artinya, ia diakui dan fisiknya dianggap bernilai di seluruh pelosok dunia dari dahulu hingga kini, sementara uang fiat hanya berharga di negara yang membuat atau mengakuinya saja dan dalam kurun waktu tertentu saja.

(6) Dengan menggunakan kembali dinar emas dan dirham perak berarti kembali kepada praktik Nabi saw. dan para Khalifah setelahnya. Selain itu, banyak hukum Islam yang ditentukan dengan emas dan perak sebagaimana dalam nisab zakat, ukuran minimal mahar, kaffarah (denda) bagi yang menyetubuhi istrinya yang sedang haid, nisab potong tangan bagi pencuri, diyat, jizyah dan lainnya. (Al-Iraqi, 2013). Bahkan di dalam al-Quran, penggunaan dinar emas dan dirham perak banyak disinggung di dalam banyak ayat, antara lain: Surat azZukhruf: 71, surat al-Insan:15-16, surat at-Taubah: 34-35, surat Yusuf 19-20, surat al-Kahf: 19, surat Ali Imran: 75, dan surat Ali Imran: 91.

(7) Manfaat memberlakukan dinar emas dan dirham perak sebagai mata uang resmi umat Islam semakin jelas dengan mengetahui sifat asal mata uang kertas yang sekarang digunakan di semua Negara dunia. Uang kertas adalah uang yang diciptakan oleh manusia untuk menggantikan emas dan perak. Banyak orang tahu bahwa sebenarnya ia tidak bernilai. Uang kertas itu berlaku atas perintah undang-undang negara yang mengeluarkannya (legal tender act), sehingga penduduk negara tersebut wajib menggunakannya atas perintah undang-undang tersebut dan bagi yang melanggarnya akan mendapat hukuman.
Dengan demikian uang kertas itu bukan uang sebenarnya tapi ia adalah nota jaminan negara. Harga yang diberi kepada uang kertas itu melebihi nilai zatnya sebagai kertas dan ini merupakan suatu ketidakadilan. Nilai nominalnya sering disalahartikan sebagai nilai intrinsik. Dan yang paling parah, nilai uang kertas selalu menyusut. Hal ini disebut inflasi. Inflasi terjadi apabila jumlah uang kertas dalam pasaran bertambah sehingga kuasa membelinya mengecil walaupun angka yang dicetak pada kertas itu masih tetap sama. Apabila nilai uang merosot maka banyak orang teraniaya karena terpaksa menggunakan lebih banyak uang kertas untuk membeli barang yang sama. Selain itu, uang fiat atau kertas diciptakan sebagai alat utama untuk memastikan sistem ekonomi yang bersandarkan hutang yang mengandungi riba dapat berjalan dengan lancar. Tanpa uang fiat seluruh sistem ini akan roboh (Al-Munawwarah, 2013).

Dan kelebihan uang emas dan perak menurut An-Nabhani sebagaimana dalam Nurlaili (2016) adalah seperti berikut: Pertama, orang tetap ramairamai memborong emas atau perak pada saat mata mata uang kuat seperti dolar AS kehilangan kepercayaan pada saat krisis. Sebabnya, emas dan perak adalah komoditi, sebagaimana komoditi lainnya, seperti kambing, besi, dan tembaga. Kedua, kestabilan moneter terjamin dengan sistem emas dan perak. Hal ini berbeda dengan sistem uang kertas yang cenderung membawa instabilitas dunia disebabkan karena uang kertas beredar dan bertambah secara tiba-tiba di tengahtengah masyarakat. Ketiga, keseimbangan neraca pembayaran antar-negara secara otomatis untuk mengoreksi ketekoran dalam pembayaran tanpa intervensi bank sentral mampu dilakukan oleh sistem emas dan perak. Ketekoran dalam perdagangan (trade imbalance) antar negara akan dapat diselesaikan dengan mekanisme ini yang disebut dengan 
automatic adjustment (penyesuaian otomatis). Keempat, kebutuhan pasar dalam pertukaran mata uang akan dapat dicukupi dengan sistem emas dan perak karena sistem ini memang mempunyai keunggulan tersebut. Kelima, sistem emas dan perak memiliki kurs yang stabil di semua negara. Keenam, sistem emas dan perak menjaga nilai kekayaan emas dan perak yang diusahakan oleh semua negara di dunia ini.(Muthoifin \& Nuha, 2016)

\section{Fungsi Uang dan Ketentuan Islam Da- lam Masalah Uang.}

Menurut perspektif ekonomi Islam, uang mempunyai fungsi yang sangat penting dalam menjalankan roda perekonomian umat. Berikut ini adalah fungsi uang dan ketentuan hukum Islam yang mengiringinya: (Iqbal, 2012)

1. Uang sebagai medium of exchange (alat tukar).

Fungsi utama uang adalah sebagai alat tukar. Dengan uang, pertukaran dapat dilakukan dengan mudah, tanpa harus menukarkan dengan barang. Sehingga dengan demikian kesulitankesulitan yang timbul akibat sistem barter sebagaimana dilakukan oleh orang-orang zaman dahulu dapat diatasi.

Dari fungsi uang sebagai alat tukar ini bisa ditarik kesimpulan bahwa uang bukan barang. Oleh karena itu uang tidak boleh jadi komoditas perdagangan seperti barang-barang lainnya. Dalam hukum Islam, uang tidak boleh diperdagangkan kecuali dengan syarat harus tunai dan harus semisal. Dua syarat ini apabila tidak dipenuhi, maka perdagangan uang akan dimasuki riba. Riba ialah tambahan tertentu tanpa imbalan yang disyaratkan dalam akad sebagai hak salah satu pihak, yang terjadi baik dalam akad hutang piutang maupun akad jual beli (Ichsan, 2007).
Menuruthukum Islam pula, baik uang maupun barang tidak boleh ditimbun. Hal ini karena ihtikar atau menimbun uang dan barang yang diperlukan publik akan menyusahkan mereka. Uang adalah alat tukar. Apabila alat tukar ini ditimbun, hal ini akan menyebabkan berkurangnya keberadaan alat tukar ini di tengahtengah masyarakat padahal mereka sangat memerlukannya. Akibatnya, roda pertukaran dan perekonomian umat akan terhambat dan tersendat. (Muthoifin, 2018)

Sebagai alat tukar, uang harus mendapat sikkah atau dicetak dan distempel pemerintah sehingga menjadi legal. Hal ini supaya uang dipercayai oleh seluruh lapisan masyarakat dan pemalsuan uang dapat diminimalisir. Individu tidak boleh sembarangan membuat uang. Siapa yang berani membuat uang palsu akan mendapat hukuman setimpal.

Sebagai alat tukar, uang itu menurut ekonomi Islam harus selalu mengalir dalam perekonomian umat. Hal ini dikenal dengan flow concept, bukan stock concept. Menurut flow concept, oleh karena uang merupakan public goods (barang milik publik) dan tidak boleh berubah menjadi private goods (barang milik pribadi), maka uang harus selalu mengalir dan beredar di tengahtengah masyarakat untuk menghidupkan perekonomian mereka. Oleh karena itu, semakin cepat perputaran uang di tengahtengah masyarakat semakin bergairah perekonomian mereka. Pandangan yang menyatakan bahwa uang bersifat stock concept yang menyatakan bahwa uang adalah salah satu cara untuk menyimpan harta kekayaan (store of wealth) adalah pandangan yang ditolak oleh ekonomi Islam. Hal ini karena perbedaan di antara keduanya. Kekayaan atau capital adalah private goods yaitu barang-barang milik pribadi yang beredar hanya pada individu 
tertentu, sedangkan uang adalah public goods yaitu barang-barang yang dimiliki oleh semua orang dan harus mengalir dan beredar di tengah-tengah mereka semua (Nurlaili, 2016).

2. Uang sebagai unit of account (satuan hitung)/measure of value (pengukur nilai).

Fungsi lain uang ialah sebagai unit of account (satuan hitung) atau measure of value (pengukur nilai). Uang sengaja diciptakan untuk menunjukkan nilai berbagai barang dan jasa yang diperjualbelikan, menunjukkan kekayaan, dan menghitung besar kecilnya hutang. Selain itu, uang berfungsi sebagai alat penunjuk harga. Dengan uang, harga barang dan jasa ditentukan, seperti menentukan nilai sebuah rumah atau mobil dengan satuan uang, seperti rupiah, dolar, dan lainnya. Sebagai satuan hitung, uang mempunyai peran yang besar dalam memperlancar pertukaran. Abu Ubaid (w. 224 H) dan Imam Ghazali (w. $505 \mathrm{H}$ ) menegaskan fungsi uang sebagai pengukur nilai ini sebagaimana dalam (Susanti, 2018). Abu Ubaid berpendapat bahwa uang dinar dan dirham merupakan nilai harga sesuatu, sementara segala sesuatu yang lain tidak bisa dijadikan sebagai nilai harga keduanya itu. Lebih jauh lagi, Imam Ghazali menyatakan dengan tegas bahwa Allah menciptakan dinar dan dirham menjadi hakim pengadil di antara seluruh harta kekayaan, agar supaya seluruh harta kekayaan itu dapat dinilai dan diukur dengan keduanya. Sebagai contoh, seekor unta menyamai 100 dinar, dan sekian ukuran minyak za'faran sama dengan 100 dinar. Oleh karena keduanya kira-kira sama dengan satu ukuran, maka keduanya mempunyai nilai yang sama.

Di samping itu, uang juga memainkan peranan religious. Peran uang dalam arti religius terletak pada realita bahwa uang bisa digunakan untuk menghitung beberapa ketentuan agama seperti nisab dan kadar zakat, ukuran minimal mahar, kaffarah (denda) bagi yang menyetubuhi istrinya yang sedang haid, nisab potong tangan bagi pencuri, diyat, jizyah dan lainnya dengan tepat (Al-Iraqi, 2013) (Muthoifin, 2019)

3. Uang sebagai store of value (penyimpan nilai).

Fungsi ketiga uang adalah sebagai penyimpan nilai. Maksudnya, uang yang dimiliki oleh seseorang itu tidak dibelanjakan seluruhnya dalam satu waktu, tapi uang akan disisihkan atau disimpan untuk keperluan di masa yang akan datang seperti untuk membeli barang atau jasa atau untuk persiapan di waktu sakit atau untuk mengantisipasi kerugian di waktu yang akan datang. Sebabnya, motivasi orang mendapat uang adalah untuk memenuhi kebutuhan hidupnya dan untuk berjaga-jaga dari kemungkinan-kemungkinan yang tidak terduga seperti kondisi di atas.

Fungsi uang sebagai penyimpan nilai ini diperselisihkan oleh para ulama (Ilyas, 2016). Sebagian ulama, seperti Mahmud Abu Su'ud mempunyai pandangan bahwa uang sebagai alat penyimpan nilai merupakan ilusi yang tidak benar. Sebabnya adalah karena uang tidak dapat dikategorikan sebagai barang komoditas seperti barang-barang lain. Uang sama sekali tidak mengandungi nilai pada bendanya. Uang hanyalah sebagai alat tukar menukar kebutuhan. Pendapat ini sejalan dengan pendapat al-Ghazali yang menyatakan bahwa uang itu diibaratkan seperti cermin. Cermin hanya dapat menilai sesuatu yang ada di depannya, tetapi ia tidak dapat menilai dirinya sendiri, demikian pula uang. Al-Ghazali juga berpendapat perdagangan uang dengan uang itu dilarang dalam Islam. Hal itu disebabkan karena fungsi uang sebagai alat pertukaran tidak berjalan. Apabila uang dapat membeli atau dibeli 
dengan uang lain, maka fungsi uang berubah, tidak lagi berfungsi sebagai alat tukar tapi sebagai komoditi. Adnan al-Turkiman juga khawatir apabila uang berperan sebagai penyimpan nilai, maka orang akan menimbun uang karena sifat alamiah uang adalah tahan lama walaupun disimpan atau ditahan dalam waktu yang lama.

Tambahan pula, pada realitasnya, harga-harga barang selalu mengalami kenaikan pesat, sementara nilai uang terus mengalami kemerosotan. Oleh karena itu, menyimpan kekayaan dalam bentuk uang bukan tindakan yang bijak, karena uang akan mengalami penurunan nilai dibanding dengan kekayaan yang berbentuk barang. Hal ini menjelaskan bahwa uang bukanlah alat penyimpan kekayaan yang baik, sehingga dengan demikian, tidak tepat apabila uang dijadikan sebagai alat menyimpan kekayaan (Al-Haritsi, 2006).

Sebagian ulama lain, mengakui fungsi uang sebagai penyimpan nilai. Argumentasi mereka antara lain motif orang untuk mempunyai uang adalah untuk transaksi (money demand for transaction) dan motiv berjaga-jaga (money demand for precautionary). Realitas menyatakan bahwa seseorang memang perlu menyimpan uangnya untuk menghadapi hal-hal yang tak terduga. Apalagi kalau uang itu berupa dinar emas dan dirham perak, ia akan menyimpan nilai untuk jangka waktu yang lama dalam keadaan stabil sebagaimana terbukti dalam sejarah.

Kekhawatiran nilai uang akan selalu merosot memang patut apabila uang tersebut uang kertas, tapi tidak untuk uang dinar emas dan dirham perak. Demikian pula kekhawatiran penimbunan uang akan terjadi apabila uang berfungsi sebagai penyimpan nilai juga bisa dibantah bahwa penimbunan uang dan demikian penimbunan barang yang dibutuhkan oleh masyarakat itu dilarang dan merupakan suatu kesalahan karena menyusahkan hidup orang banyak. Adapun kekhawatiran uang akan menjadi komoditas yang diperdagangkan sebagaimana layaknya barang-barang pada umumnya, bisa dibantah bahwa Islam membenarkan pertukaran uang (valas), dengan dua syarat; pertama: transaksi tersebut harus tunai, dalam artian bahwa uang yang dpertukarkan harus diserah terimakan secara langsung dan tidak ada penyerahan salah satunya atau kedua-duanya, dan kedua: harus semisal, artinya apabila rupiah ditukar rupiah maka nominalnya harus sama. Tapi kalau dolar ditukar rupiah, maka nominalnya boleh berbeda.

Selain itu, fungsi uang sebagai penyimpan nilai tidak bertentangan flow concept, karena yang penting menurut konsep ini adalah bahwa uang harus selalu mengalir dan beredar di tengah-tengah untuk menghidupkan perkonomian. Hal ini karena uang itu adalah public goods (barang publik), tidak boleh mengendap menjadi private goods (milik pribadi) Pendapat yang menyatakan bahwa uang bersifat stock concept, yaitu konsep yang menyatakan bahwa uang adalah salah alat atau cara untuk menyimpan harta kekayaan (store of wealth) adalah pendapat yang ditolak dalam Islam. Sebabnya menurut Rahmawaty (2013) ialah hakikat keduanya itu berbeda. Kekayaan atau capital adalah private goods yaitu benda-benda milik pribadi yang hanya beredar pada individu tertentu saja. Sementara uang adalah public goods yaitu benda-benda yang dimiliki oleh semua orang dan harus beredar dan berputar di tengah-tengah mereka semua.

Seorang ekonom, Michael Maloney, menegaskan bahwa fungsi uang sebagai penyimpan nilai hanya bisa dilakukan apabila uang berbentuk emas dan perak, bukan kertas. Dia menyatakan bahwa apapun yang disebut uang oleh 
masyarakat dunia pada hakikatnya hanyalah sebuah alat tukar yang bersifat sesaat (currency). Currency tidak akan pernah mampu menjadi sebuah simpanan nilai atau sering disebut sebagai store of value. Syarat yang dimiliki store of values haruslah dapat disebut sebagai uang (dapat diuangkan). Sementara, yang disebut sebagai uang berarti harus mampu mempunyai dua fungsi, yaitu store of value dan bisa dijadikan sebagai alat tukar. Jadi, uang tentu saja bisa disebut sebagai currency, tetapi currency belum tentu berupa uang. Dan yang mampu berperan seperti seperti itu menurut Michael hanyalah emas dan perak saja. Sejak dulu sampai sekarang, emas mempunyai nilai store of value dan juga bisa dipakai sebagai alat tukar (Dipraja, 2011).

Dengan demikian dapat dikatakan bahwa yang paling penting dari sifat atau fungsi uang adalah nilainya yang stabil dalam waktu yang lama. Terbukti sepanjang sejarah bahwa sifat itu hanya bisa dipenuhi oleh dinar emas dan dirham perak.

\section{PENUTUP}

Dalam perspektif ekonomi Islam, uang adalah segala sesuatu yang diterima secara umum dan diterbitkan oleh lembaga keuangan yang berwenang sebagai media pertukaran dan pengukur serta penyimpan nilai. Uang dinar emas dan dirham perak sudah dipakai sebagai mata uang resmi sejak zaman Nabi Muhammad saw. dan diteruskan oleh para khalifah setelahnya selama berabadabad lamanya. Meskipun penggunaan uang dinar emas dan dirham perak bukan suatu kewajiban, namun sejarah membuktikan bahwa dua mata uang tersebut sangat stabil dan tidak terkena inflasi sebagaimana uang kertas. Uang mempunyai tiga fungsi yaitu sebagai alat pertukaran, satuan hitung atau pengukur nilai, dan penyimpan nilai apabila uang terbuat dari emas dan perak. Yang paling penting dari sifat atau fungsi uang adalah nilainya yang stabil. Islam mempunyai ketentuan dalam bidang keuangan seperti menggunakan uang sebagai alat pengukur nisab dan kadar zakat, mahar, kaffarah (denda) bagi yang menyetubuhi istrinya yang sedang haid, nisab potong tangan bagi pencuri, diyat, dan jizyah. Islam melarang jual beli dan hutang-piutang dengan cara ribawi dan menimbun uang dan barang yang dibutuhkan oleh masyarakat luas.

\section{DAFTAR PUSTAKA}

Al-Haritsi, J. (2006). Fikih Ekonomi Umar bin Khattab. Jakarta: Khalifa.

Al-Iraqi, A. (2013). Al-Takyiif al-Fiqhi li al-Nizaam al- Naqdi al-Haali. Paris: Al-Ma'had al-Aurubi li al-Ulum al-Insaniyah - al-Kulliyyah al-Aurubiyyah li al-Dirasat al-Islamiyyah. Makalah tidak diterbitkan.

Al-Munawwarah, A. (2013). Hujjah Terang Benderang Untuk Mengembalikan Wang Suci Kita. Tanpa tempat dan nama penerbit.

Ari, Y. (2013). Investasi Emas Untuk Ibu Rumah Tangga. Yogyakarta: Suaka Media.

Dipraja, S. (2011). Siapa Bilang Investasi Emas Butuh Modal Gede? Jakarta: PT. Tangga Pustak).

Ichsan, M. (2007). Hidup Tenang Tanpa Hutang. Yogyakarta: Mocomedia.

Ichsan, M. (2017). The Use of Gold Dinar and Silver Dirham in Moslem Countries in the Contemporary Era. Jurnal Media Hukum, 24(1), 35-41. https://doi.org/10.18196/ jmh.2017.0087.35-41 
Ilyas, R. (2016). Konsep Uang Dalam Perspektif Ekonomi Islam. BISNIS : Jurnal Bisnis Dan Manajemen Islam, 4(1), 35-57. https://doi.org/10.21043/bisnis.v4i1.1695

Iqbal, M. (2012). Konsep Uang Dalam Islam. Jurnal Ekonomi Islam Al-Infaq, 3(2), 294-317.

Karim, A. (2007). Ekonomi Makro Islam. Jakarta: PT Raja Grafindo Persada.

Kurniawan, EJ. (2012). Think Dinar! Depok: AsmaNadia Publishing House.

Muthoifin. (2019). Shariah hotel and mission religion in surakarta indonesia. Humanities and Social Sciences Reviews, 7(4), 973-979. https://doi.org/10.18510/hssr.2019.74133

Muthoifin. (2018). Mengungkap Isi Pendidikan Islam Perspektif Al- Qur' an Surat Al -Ashr Ayat 1-3. Mengungkap Isi Pendidikan Islam Perspektif Al-Qur'an Surat Al-Ashr Ayat 1-3, 206-218.

Muthoifin. (2013). Urgensitas dan Kontekstualisasi Kisah-Kisah Al- Qur' an Untuk Pendidikan dan Pembelajaran. Urgensitas Dan Kontekstualisasi Kisah-Kisah Al-Qur ' an Untuk Pendidikan Dan Pembelajaran, 106-110.

Muthoifin, \& Nuha. (2016). the Optimization of Local Autonomy Politic for Nation Progress and Synergetic on Islamic Perspective. The 4th University Research Coloquium 2016, 72-79. https://publikasiilmiah.ums.ac.id/xmlui/handle/11617/7679

Nurlaili. (2016). Uang Dalam Prespektif Ekonomi Islam (Depresiasi Nilai Rupiah). Ikonomika, I(I), 79-91.

Rahmawaty, A. (2013). Uang Dan Kebijakan Moneter Dalam Perspektif Ekonomi Islam. Equilibrium, 1(2), 181-199.

Sanhu, A. (2012). Membeli Emas Perhiasan. Yogyakarta: Lukita.

Susanti, R. (2018). Sejarah Transformasi Uang Dalam Islam. Aqlam: Journal of Islam and Plurality, 2(1). https://doi.org/10.30984/ajip.v2i1.509

Takiddin. (2014). Uang Dalam Perspektif Ekonomi Islam. SALAM: Jurnal Filsafat Dan Budaya Hukum, 1(2). https://doi.org/10.15408/sjsbs.v1i2.1539 